\title{
Electrosynthesis of Ce-Co Mixed Oxide Nanotubes with High Aspect Ratio and Tunable Composition
}

\author{
Patrizia Bocchetta, ${ }^{\mathrm{z}}$ Monica Santamaria, ${ }^{*}$ and Francesco Di Quarto* \\ Dipartimento di Ingegneria Chimica dei Processi e dei Materiali, Università di Palermo, 90128 Palermo, \\ Italy
}

An electrochemical synthetic route is developed to produce cerium-cobalt mixed oxide nanotubes with tunable composition. The process consists of a template-assisted electrogeneration of base from a cerium-cobalt nitrate solution of different compositions. From scanning electron microscopy studies it is seen that Ce-Co oxide nanotubes of high aspect ratio and ordered structures are formed. Energy-dispersive X-ray analysis shows a linear relationship between the solution and the oxide composition [Ce/(Ce $+\mathrm{Co}$ ) atomic ratio].

(C) 2008 The Electrochemical Society. [DOI: 10.1149/1.2823260] All rights reserved.

Manuscript submitted October 15, 2007; revised manuscript received November 6, 2007. Available electronically January 9, 2008.

Cerium oxide and cobalt oxides have attracted the interest of several researchers due to their potential application in several technological fields (electrochromism, lithium batteries, catalysis, etc.). Ceria has been used as a promoter in the so-called "three-way catalyst" for the control of toxic emission from automobile exhaust. The promotion consists of the enhancement of the noble metal dispersion, as well as stabilization of the supporting medium toward thermal sintering. ${ }^{1,2}$ A direct catalytic effect of $\mathrm{CeO}_{2}$ in chemical processes such as water-gas shift reaction or $\mathrm{NO}_{x}$ decomposition has been also evidenced. ${ }^{3,4}$ Concerning $\mathrm{Co}_{3} \mathrm{O}_{4}$, several papers have reported on its beneficial role in the oxidation of carbon monoxide ${ }^{5-8}$ and methane. ${ }^{9}$ Recent works have demonstrated that the addition of ceria to cobaltic oxide allows cocatalyst production, with better performances with respect to pure $\mathrm{Co}_{3} \mathrm{O}_{4}$ in terms of higher thermal stability and catalytic activity. ${ }^{10-15}$ Ceria-based electrolytes are the most promising alternative to yttria-stabilized zirconia as a fast ionic conductor for solid oxide fuel cells, with the advantage of a lower operating temperature. ${ }^{16-18}$ In recent years the increased interest in these materials has lead to many investigations aimed at studying efficient processes for the fabrication of ceria powders as well as to improve their sinterability. According to Ref. 19 and 20, the addition of a small amount of cobalt oxide to gadolinia-stabilized ceria resulted in much lower sintering temperature, higher shrinkage rates, and grain sizes in the final sintered product in the submicrometer range.

If we consider that the activity of catalysts can be enhanced by a high surface area to bulk ratio, the possibility of finding a process for the fabrication of cerium-cobalt mixed oxides with smart morphologies, such as one-dimensional (1D) nanostructures, seems appealing and challenging.

In recent years cerium oxide and cobalt oxide nanowires have been produced through several methods, such as a template-assisted sol-gel process, nonisothermal precipitation, spontaneous selfassembly of cerium oxide nanoparticles to nanorods, and a solutionbased hydrothermal process. ${ }^{21}$ However, only a few studies have addressed the fabrication of $\mathrm{Co}$ or $\mathrm{Ce}$ oxide nanostructures with hollow interiors, usually called nanotubes (NTs), ${ }^{22-26}$ and as far as the authors know, no data are reported in the literature about the preparation of mixed $\mathrm{Ce}-\mathrm{Co}$ oxide NTs. Ceria NTs have been prepared by a hydrothermal process, without or with the employment of a template, i.e., organic molecules or carbon NTs. The fabrication of cobalt oxide NTs seems more difficult, because according to the few papers reporting on the production of $\mathrm{Co}_{3} \mathrm{O}_{4} \mathrm{NTs}$, they are currently produced by calcination of cobalt complex precursor/polystyrene layers coated onto colloidal particles, ${ }^{25}$ or by calcining cobalt nanowires previously deposited into an anodic alumina membrane (AAM) under alternate current. ${ }^{26}$

\footnotetext{
* Electrochemical Society Active Member.

z E-mail: bocchetta@dicpm.unipa.it
}

Electrogeneration of base is a well-established, low-cost technique for the preparation of metal oxides and hydroxides starting from the metal nitrate solution. ${ }^{27,28}$ It has been recently demonstrated ${ }^{29-31}$ that this method can be extended to the preparation of 1D metal oxide and hydroxide nanostructures by using an AAM template.

In this article we report on the possibility of using the same electrochemical route for the synthesis at room temperature of cerium oxide, cobalt oxide, and cerium-cobalt mixed oxyhydroxide NTs with a tunable Ce/Co ratio. Moreover, we show how the use of an AAM as a template for the direct synthesis of these materials allows ordered and high-aspect-ratio arrays of high-quality NTs to be obtained.

\section{Experimental}

Commercial AAMs (Anodisc-60 Whatman, average pore diameter $200 \mathrm{~nm}$, porosity 43\%) were employed as a template. Gold was sputtered on one side of the membrane to serve as the conductive layer. The AAM was supported in a holder in order to delimit the electrode area exposed to the solution $\left(2.54 \mathrm{~cm}^{2}\right)$. The electrodeposition process was carried out in aqueous $0.05 \mathrm{M} \mathrm{Ce}\left(\mathrm{NO}_{3}\right)_{3}(\mathrm{pH} 4.1)$ and/or $0.05 \mathrm{M} \mathrm{Co}\left(\mathrm{NO}_{3}\right)_{2}(\mathrm{pH} 4.8)$ solutions by applying a constant current density of $1 \mathrm{~mA} \mathrm{~cm}^{-2}$ with a multichannel potentiostat VMP2 (Princeton Applied Research). A classic three-electrode cell was employed with the AAM as working electrode, a dimensionally stable anode electrode as counter electrode, and a saturated calomel electrode (SCE) as reference electrode. The AAM/NT samples were sometimes chemically etched in $0.1 \mathrm{M} \mathrm{NaOH}$ in order to remove the alumina host. Thermal treatment of AAM/NT samples was realized in an oven at $500^{\circ} \mathrm{C}$ in air.

Morphology and quality of the NTs were investigated using a Philips XL30 ESEM scanning electron microscope (SEM). Energydispersive X-ray analysis (EDX) was also performed in order to identify the elements in the deposited materials and to determine their composition. X-ray analysis of composite AAM/ NT arrays was realized by a Philips X-Ray Generator (model PW 1130) and a PW (model 1050) goniometry. The identification was performed according to the International Centre for Diffraction Data (ICDD) cards available.

\section{Results and Discussion}

As previously shown, ${ }^{27,28}$ the mechanism of electrogeneration of base is an electrochemical method for the deposition of metal oxides and/or hydroxides involving the cathodic reduction of nitrate ions and generation of $\mathrm{OH}^{-}$ions according to Eq. 1

$$
\mathrm{NO}_{3}^{-}+\mathrm{H}_{2} \mathrm{O}+2 \mathrm{e}^{-} \rightarrow \mathrm{NO}_{2}^{-}+2 \mathrm{OH}^{-}
$$

with consequent local increase of $\mathrm{pH}$ sufficient to induce the chemical precipitation of many metal hydroxides and/or oxides at the electrode/solution interface, according to the reaction 


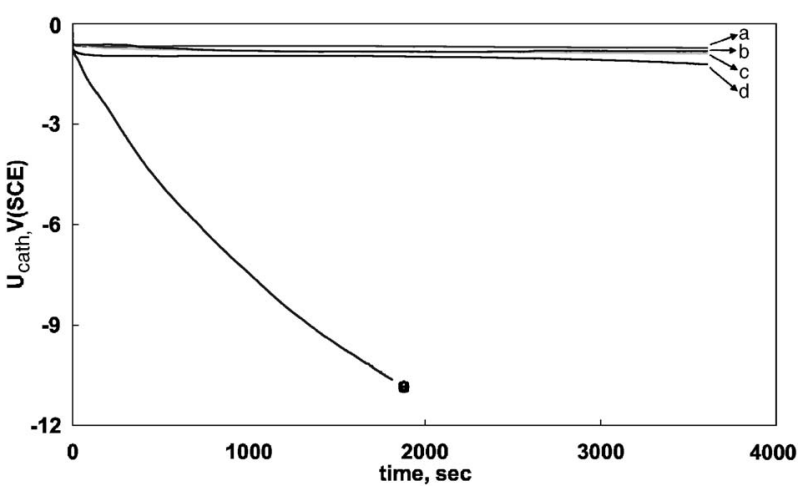

Figure 1. Potential (reference SCE) vs time curve during the electrodeposition of $\mathrm{Ce} / \mathrm{Co}$ oxide NTs inside porous AAM at $i=1 \mathrm{~mA} / \mathrm{cm}^{2}$, total concentration $0.05 \mathrm{M}$ metal nitrate, and different atomic ratios $\mathrm{Ce} /(\mathrm{Ce}+\mathrm{Co})$ in the starting electrolyte: (a) 0.8 ; (b) 0.5 ; (c) 0.2 ; (d) 1 ; and (e) 0 .

$$
\mathrm{M}^{z+}+z \mathrm{OH}^{-} \rightarrow \mathrm{M}(\mathrm{OH})_{z} \downarrow
$$

Thus, in order to create the right conditions for the hydroxides precipitation, the AAM/Au substrates were cathodically polarized in a solution containing $\mathrm{Co}\left(\mathrm{NO}_{3}\right)_{2}$ and/or $\mathrm{Ce}\left(\mathrm{NO}_{3}\right)_{3}$ by imposing a cathodic current density of $1 \mathrm{~mA} \mathrm{~cm}{ }^{-2}$.

In Fig. 1 we report the voltage vs time curves recorded during the cathodic electrodeposition from $\mathrm{Co}\left(\mathrm{NO}_{3}\right)_{2}$ and/or $\mathrm{Ce}\left(\mathrm{NO}_{3}\right)_{3}$ containing solutions. With the exception of the electrodeposition from the cobalt nitrate solution, after an initial drop from the open-circuit potential to around $-0.6 \mathrm{~V} / \mathrm{SCE}$, an almost constant voltage is reached (between -1.2 and $-1.75 \mathrm{~V} / \mathrm{SCE}$ ), suggesting that the electrochemical process, and thus the thickening of the nanodeposits, occurs at nearly constant overpotential. The equilibrium potential of the half-cell reaction (Eq. 1) is given by

$$
\text { E V }(\mathrm{SCE})=0.595-0.0591 \mathrm{pH}+0.0295 \log \left(\mathrm{NO}_{2}^{-} / \mathrm{NO}_{3}^{-}\right)
$$

At $\mathrm{pH} 4.8$ and with $\left[\mathrm{NO}_{3}^{-}\right]=0.11 \mathrm{M}$, by assuming $\left[\mathrm{NO}_{2}^{-}\right]$ $=10^{-6} \mathrm{M}$ the equilibrium potential for the reduction of nitrate ion to nitrite ion is $+0.16 \mathrm{~V}$ ( $\mathrm{SCE}$ ), thus being thermodynamically possible at the more cathodic potential reached during the electrodeposition. Hydrogen evolution and oxygen reduction are not excluded, but they are both accompanied by a local increase of $\mathrm{OH}^{-}$ion concentration, which further supports the subsequent hydroxide precipitation.

When only $\mathrm{Co}^{2+}$ ions are present in the electrodeposition bath (Fig. 1e), the electrode potential increases cathodically, reaching very negative values, thus suggesting that the thickening of the deposits is sustained by an increasing electrode potential. This behavior can be attributed to the electronic properties of $\mathrm{Co}(\mathrm{OH})_{2}$, which is reported to be a p-type semiconductor, ${ }^{32}$ thus behaving like a Schottky barrier under reverse bias. In this case the thickening of the nanodeposits introduces in the potential vs time curve a further potential drop that increases with deposition time. The absence of such dependence for Ce-containing nanodeposits can be explained by the n-type semiconducting properties of $\mathrm{CeO}_{2}$ (Ref. 33) and suggests for the $\mathrm{Ce} / \mathrm{Co}$ mixed oxides an n-type character.

Figure 2 shows the X-ray diffraction (XRD) patterns of AAM/ NTs soon after preparation. The broad feature in the spectra arises from the amorphous AAM substrate. The NTs grown from pure cerium nitrate solution (Fig. 2a) are crystalline, with diffraction peaks that can be assigned to $\mathrm{CeO}_{2}$ (ICCD card no. 34-0394) and to $\mathrm{Ce}(\mathrm{OH})_{3}$ (ICCD card no. 19-0284), in agreement with the yellowbrown appearance of the samples. The widely accepted mechanism of cathodic deposition of cerium in the IV oxidation state $\left(\mathrm{CeO}_{2}\right)$ from $\mathrm{Ce}(\mathrm{III})$ in the solution ${ }^{34,35}$ is based on the reduction of $\mathrm{O}_{2}$ gas, dissolved into the solution, to hydrogen peroxide, and subsequent oxidation of $\mathrm{Ce}$ (III) to $\mathrm{Ce}$ (IV) according to

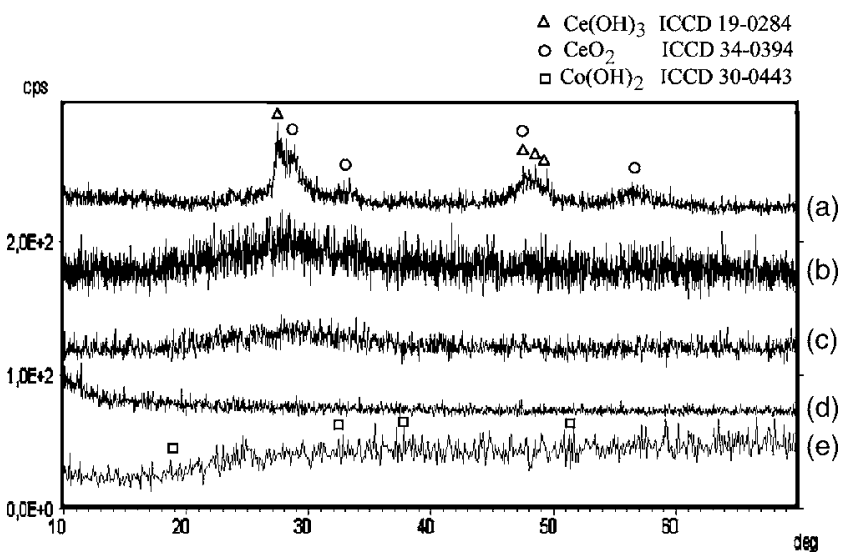

Figure 2. X-ray diffractograms of as-electrodeposited Ce/Co oxide NTs inside porous $\mathrm{AAM}$ at different atomic ratios $\mathrm{Ce} /(\mathrm{Ce}+\mathrm{Co})$ in the starting electrolyte (total concentration $0.05 \mathrm{M}$ metal nitrate): (a) 1; (b) 0.8 ; (c) 0.5 ; (d) 0.2 ; and (e) 0 .

$$
\begin{gathered}
\mathrm{O}_{2}+2 \mathrm{H}_{2} \mathrm{O}+2 \mathrm{e}^{-} \rightarrow \mathrm{H}_{2} \mathrm{O}_{2}+2 \mathrm{OH}^{-} \\
2 \mathrm{Ce}^{3+}+2 \mathrm{OH}^{-}+\mathrm{H}_{2} \mathrm{O}_{2} \rightarrow 2 \mathrm{Ce}(\mathrm{OH})_{2}^{2+} \\
2 \mathrm{Ce}(\mathrm{OH})_{2}^{2+}+4 \mathrm{OH}^{-} \rightarrow 2 \mathrm{CeO}_{2}+2 \mathrm{H}_{2} \mathrm{O}
\end{gathered}
$$

corresponding to the following overall cathodic process

$$
2 \mathrm{Ce}^{3+}+4 \mathrm{OH}^{-}+\mathrm{O}_{2}+2 \mathrm{e}^{-} \rightarrow 2 \mathrm{CeO}_{2}+2 \mathrm{H}_{2} \mathrm{O}
$$

which is operating during the electrodeposition, presumably in parallel with the nitrates reduction, leading to the direct $\mathrm{Ce}(\mathrm{OH})_{3}$ precipitation.

After thermal treatment some peaks relative to $\mathrm{Ce}(\mathrm{OH})_{3}$ seem to disappear (see Fig. 3b), indicating Ce(III) oxidation to Ce(IV) by oxygen. The transformation is evidenced also by a change in the color of the AAM/ NTs from yellow-brown to light yellow.

In contrast, the nanostructures grown from pure $\mathrm{Co}\left(\mathrm{NO}_{3}\right)_{2}$ solution seem to be amorphous or scarcely crystalline (see Fig. 2e). The evident blue-green color of the samples soon after the electrodeposition suggests the presence of $\mathrm{Co}(\mathrm{OH})_{2}$ into the AAM pores. Looking at the X-ray analysis performed on the same samples after thermal treatment $\left(500^{\circ} \mathrm{C}, 4 \mathrm{~h}\right.$, air), some peaks attributed to cubic $\mathrm{Co}_{3} \mathrm{O}_{4}$ (ICDD card no. 42-1467) appear, in agreement with the black color of the annealed samples (Fig. 3a).

Concerning the $\mathrm{Ce}-\mathrm{Co}$ mixed oxides containing electrodeposits, the only scarcely visible diffraction peaks are those attributed to $\mathrm{CeO}_{2}$ and $\mathrm{Ce}(\mathrm{OH})_{3}$ (see Fig. 2b-d). Moreover, a gradual decrease and widening of the peak intensity is observed with the decrease of

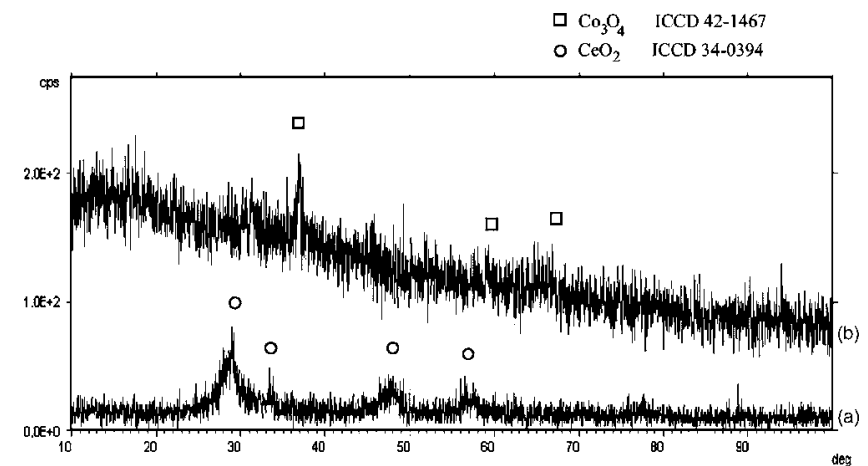

Figure 3. X-ray diffractograms of oxide NTs electrodeposited inside porous AAM from (a) pure $\mathrm{Co}\left(\mathrm{NO}_{3}\right)_{2}$ and (b) $\mathrm{Ce}\left(\mathrm{NO}_{3}\right)_{3}$ electrolytes after thermal treatment in air at $500^{\circ} \mathrm{C}$ for $4 \mathrm{~h}$. 


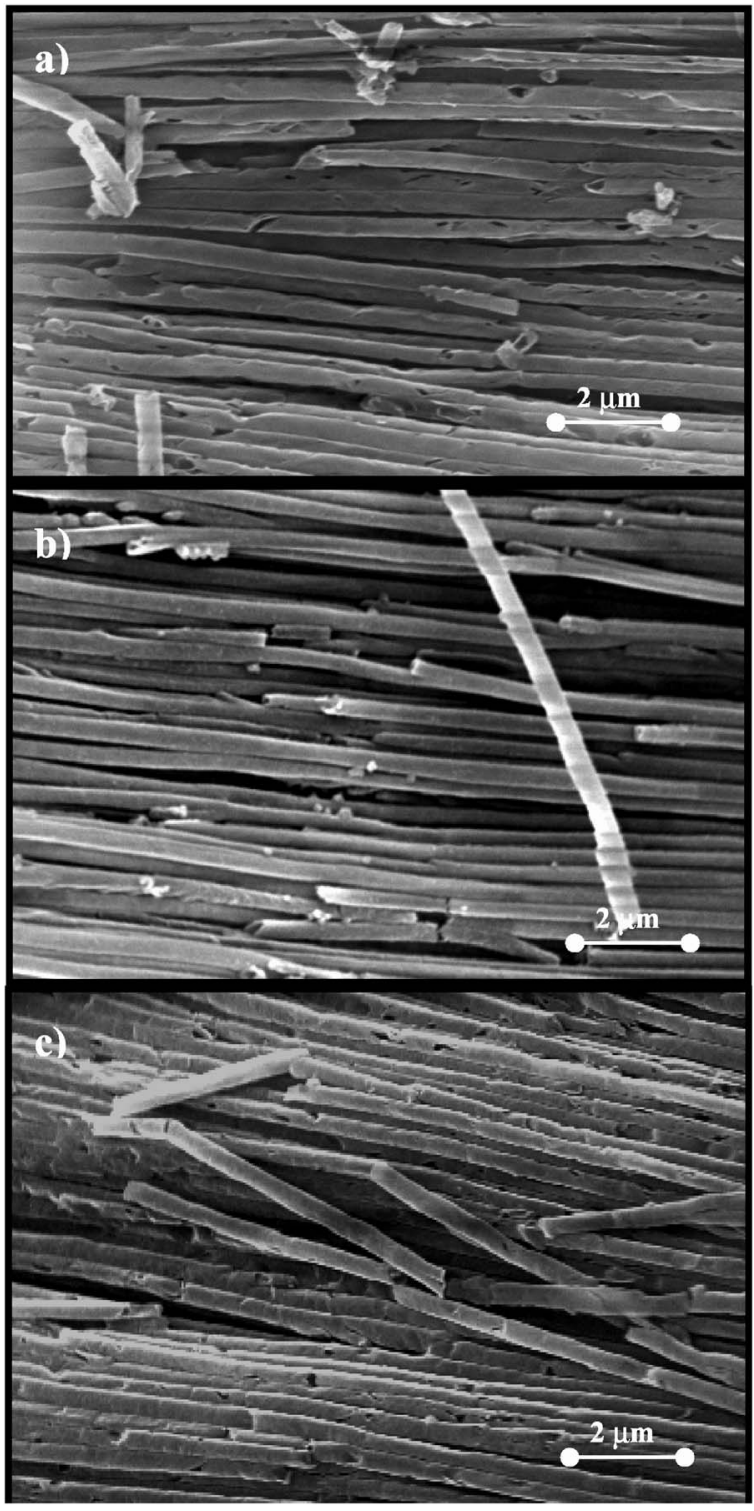

Figure 4. SEM image of the side view of freestanding Ce/Co oxide NTs after removal of the template membrane by chemical etching in $0.1 \mathrm{M} \mathrm{NaOH}$ solution at different atomic ratios $\mathrm{Ce} /(\mathrm{Ce}+\mathrm{Co})$ in the starting electrolyte (total concentration $0.05 \mathrm{M}$ metal nitrate): (a) 1; (b) 0.5; and (c) 0 .

$\mathrm{Ce} / \mathrm{Co}$ ratio in the electrolyte. These findings agree with previous results found for thin-film $\mathrm{Ce} / \mathrm{Co}$ oxide, ${ }^{36}$ where the presence of $\mathrm{CeO}_{2}$ nanocrystals in $\mathrm{Ce}-\mathrm{Co}$ mixed oxide amorphous matrix has been evidenced. In the same paper IR adsorption spectra of the $\mathrm{Ce} / \mathrm{Co}$ composite films reveal a new peak, not present in the spectra of pure $\mathrm{CeO}_{2}$ or $\mathrm{Co}(\mathrm{OH})_{2}$, assigned to $\mathrm{Ce}-\mathrm{O}-\mathrm{Co}$ bridging vibration. This result suggests that the deposit is a mixed oxide and not an aggregate of $\mathrm{CeO}_{2}$ and $\mathrm{Co}(\mathrm{OH})_{2}$.

The XRD patterns recorded for thermal treated Ce/Co mixed NTs did not show any appreciable difference with respect to those relating to as-prepared samples. This indicates that up to this temperature the mixed NTs keep their amorphous structure.

The SEM side views (Fig. 4) of pure $\mathrm{Ce}(\mathrm{OH})_{3} / \mathrm{CeO}_{2}$ (Fig. 4a), $\mathrm{Ce} / \mathrm{Co}$ mixed oxides (Fig. 4b), and pure $\mathrm{Co}(\mathrm{OH})_{2}$ (Fig. 4c) NTs after removal of the AAM template show that the tubes are continuous and uniform throughout the entire length and are arranged roughly parallel to each other. The typical morphologies of NTs are better evidenced in Fig. 5. SEM measurements reveal that the NTs have

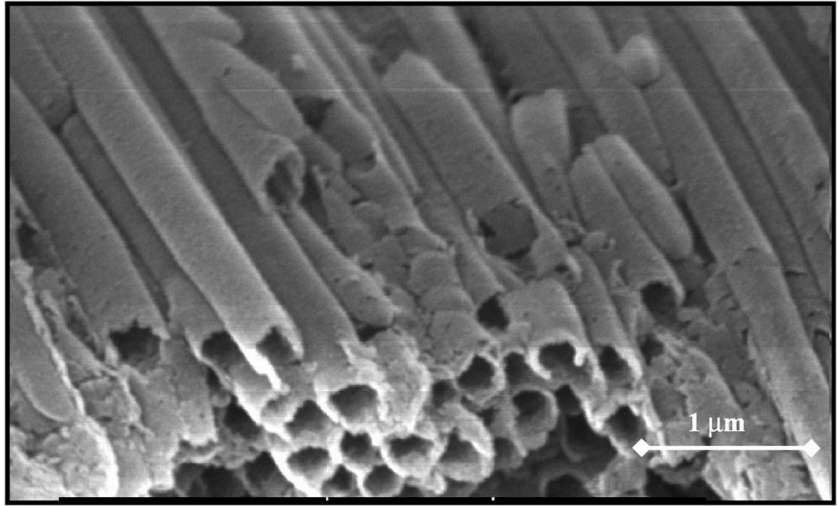

Figure 5. SEM magnification of $\mathrm{Ce} / \mathrm{Co}$ oxide $\mathrm{NTs}$ at $\mathrm{Ce} /(\mathrm{Ce}+\mathrm{Co})$ atomic ratio $=0.8$ after removal of the template membrane in $0.1 \mathrm{M} \mathrm{NaOH}$

internal diameters of $\sim 200 \mathrm{~nm}$ and lengths of $\sim 30$ to $50 \mu \mathrm{m}$, corresponding to a high aspect ratio of $150-250$.

According to experimental findings collected with several metal nitrate solutions, we believe that the formation of hollow interior nanostructures is related to the morphology of the Au layer sputtered on the AAM template, as will be discussed in a forthcoming paper.

In Fig. 6a we report the typical EDX spectrum relating to mixed $\mathrm{Ce}-\mathrm{Co}$ oxyhydroxide NTs. As shown in Fig. 6b, a quite linear relationship between the $\mathrm{EDX} \mathrm{Ce} /(\mathrm{Ce}+\mathrm{Co})$ atomic ratio revealed into
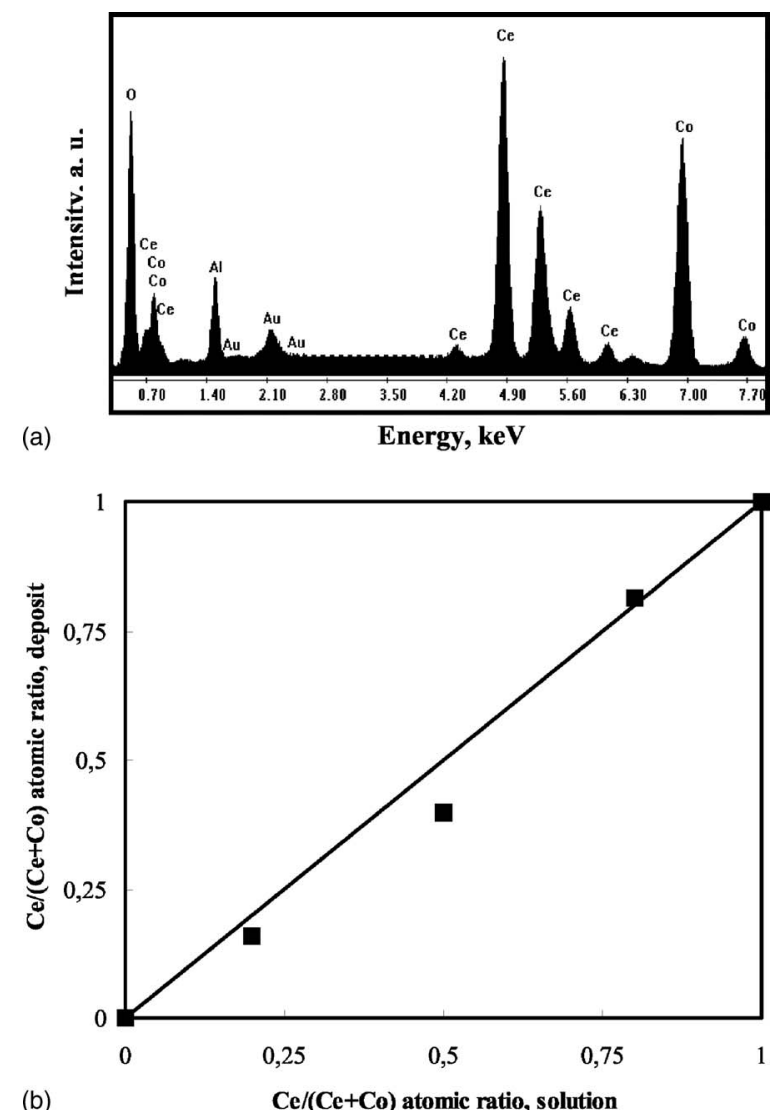

Figure 6. (a) Typical EDX spectrum of $\mathrm{Ce} / \mathrm{Co}$ oxide NTs at $\mathrm{Ce} /(\mathrm{Ce}+\mathrm{Co})$ atomic ratio $=0.5$. (b) $\mathrm{Ce} /(\mathrm{Ce}+\mathrm{Co})$ atomic ratio revealed by EDX into the deposits as a function of $\mathrm{Ce} /(\mathrm{Ce}+\mathrm{Co})$ atomic ratio in the electrodeposition solution (total concentration $0.05 \mathrm{M}$ metal nitrate). Each point is averaged on at least four measurements. 
the NTs and the $\mathrm{Ce} /(\mathrm{Ce}+\mathrm{Co})$ in the electrodeposition bath has been revealed, suggesting that the deposit formation is not influenced by the nature of the cation, but it depends on the relative amount of $\mathrm{Co}^{2+}$ and $\mathrm{Ce}^{3+}$ present in the electrolyte. This is expected for an oxyhydroxide formation precipitation mechanism not controlled by $\mathrm{OH}^{-}$concentration, which is kept high by the electrochemical process.

\section{Conclusions}

Cerium oxyhydroxide, cobalt hydroxides, and Ce-Co mixed oxyhydroxide NTs were successfully prepared at room temperature by a template-assisted process via electrogeneration of base. The NTs are continuous and uniform throughout the entire length and are arranged roughly parallel to each other. According to the morphological analysis performed by SEM, the NT internal diameter is $\sim 200 \mathrm{~nm}$, while their length is approximately $30-50 \mu \mathrm{m}$, corresponding to a high aspect ratio of 150-250. The NT diameter, thickness, and density can be also tuned in a wide range of values by simply changing the AAM template morphology. ${ }^{37}$ The $\mathrm{Ce}-\mathrm{Co}$ mixed oxyhydroxide NTs have a variable composition with a $\mathrm{Co} / \mathrm{Ce}$ ratio very close to that of the electrodeposition solution. This aspect makes the AAM template-assisted electrodeposition a very powerful technique for tailoring the composition of the growing mixed oxide nanostructures. Moreover, in the specific case of Ce-Co mixed oxyhydroxide employed as catalyst, NTs embedded AAM can be directly used as catalyst, because alumina is usually used as catalyst support for high-temperature applications.

\section{Acknowledgments}

The authors gratefully acknowledge USAITC-A (grant no. W911NF-07-1-0564) and University of Palermo (Italy) for financial support. One of the authors (P.B.) gratefully thanks Regione Sicilia (Program APQ Ricerca "Laboratorio dell'innovazione nel settore dei beni culturali"- delibera CIPE no. 17/2003) for providing a fellowship. article.

University of Palermo assisted in meeting the publication costs of this

\section{References}

1. A. Trovarelli, Catal. Rev. - Sci. Eng., 38, 439 (1996).

2. R. Dictor and S. Roberts, J. Phys. Chem., 93, 5846 (1989); E. C. Su and W. G. Rothschild, J. Catal., 99, 506 (1986).

3. T. Shido and Y. Iwasawa, J. Catal., 136, 493 (1992); T. Shido and Y. Iwasawa, J. Catal., 141, 71 (1993).

4. A. Martinez-Arias, J. Soria, J. C. Coneca, X. L. Seoane, A. Arcoya, and R. Cataluna, J. Chem. Soc., Faraday Trans., 91, 1679 (1995).

5. J. Jansson, J. Catal., 194, 55 (2000).

6. H.-K. Lin, C.-B. Wang, H.-C. Chiu, and S-H. Chien, Catal. Lett., 86, 63 (2003).

7. H.-K. Lin, H.-C. Chiu, H.-C. Tsai, S.-H. Chien, and C.-B. Wang, Catal. Lett., 88,
169 (2003).

8. C.-B. Wang, C.-W. Tang, S.-J. Gau, and S.-H. Chien, Catal. Lett, 101, 59 (2005).

9. J. G. McCarthy, Y.-F. Chang, V. L. Wong, and M. E. Johansson, Prepr. Pap. - Am. Chem. Soc., Div. Fuel Chem., 42, 158 (1997).

10. J. Kirchnerova, M. Alifanti, and B. Delmon, Appl. Catal., A, 231, 65 (2002).

11. M. Kang, M. W. Song, and C. H. Lee, Appl. Catal., A, 251, 143 (2003).

12. M. M. Natile and A. Glisenti, Chem. Mater, 17, 3403 (2005).

13. L. F. Liotta, G. Di Carlo, G. Pantaleo, A. M. Venezia, and G. Deganello, Appl. Catal., B, 66, 217 (2006).

14. C.-W. Tang, C.-C. Kuo, M.-C. Kuo, C.-B. Wang, and S.-H. Chien, Appl. Catal., A, 309, 37 (2006).

15. L. F. Liotta, G. Di Carlo, G. Pantaleo, and G. Deganello, Appl. Catal., B, 70, 314 (2007).

16. I. Riess, M. Gödickemeier, and L. J. Gauckler, Solid State Ionics, 90, 91 (1996).

17. M. Godickemeier and L. J. Gauckler, J. Electrochem. Soc., 145, 414 (1998).

18. B. C. H. Steele, Solid State Ionics, 129, 95 (2000).

19. E. Jud, L. Gauckler, S. Halim, and W. Stark, J. Am. Ceram. Soc., 89, 2970 (2006).

20. C. Kleinlogel and L. J. Gauckler, Adv. Mater, 13, 1081 (2001).

21. R.-J. La, Z.-A. Hu, H.-L. Li, X.-L. Shang, and Y.-Y. Yang, Mater. Sci. Eng., A, 368, 145 (2004); H.-I. Chen and H.-Y. Chang, Solid State Commun., 133, 593 (2005); G. S. Wu, T. Xie, X. Y. Yuan, B. C. Cheng, and L. D. Zhang, Mater. Res. Bull., 39, 1023 (2004); S. C. Kuiry, S. D. Patil, S. Deshpande, and S. Seal, J. Phys. Chem. B, 109, 6936 (2005); C. Ho, J. C. Yu, T. Kwong, A. C. Mak, and S. Lai, Chem. Mater, 17, 4514 (2005); R. Yang and L. Guo, J. Mater. Sci., 40, 1305 (2005); C. Sun, H. Li, H. Zhang, Z Wang, and L Chen, Nanotechnology, 16, 1454 (2005); R. Si, Y.-W. Zhang, L.-P. You, and C.-H. Yan, Angew. Chem., Int. Ed., 44, 3256 (2005); T. Yu, J. Joo, Y. I. Park, and T. Hyeon, Angew. Chem., Int. Ed., 44, 7411 (2005); B. Tang, L. Zhuo, J. Ge, G. Wang, Z. Shi, and J. Niu, Chem. Commun., 2005, 3565; G. Zhang, Z. Shen, M. Liu, C. Guo, P. Sun, Z. Yuan, B. Li, D. Ding, and T. Chen, J. Phys. Chem. B, 110, 25782 (2006); D. Barreca, A. Gasparotto, C. Maccato, C. Maragno, and E. Tondello, Langmuir, 22, 8639 (2006); E. Hosono, S. Fujihara, I. Homma, and H. Zhou, J. Mater. Chem., 15, 1938 (2005); Y. C. Chen and Y. G. Zhang, Chin. J. Chem. Phys., 17, 481 (2004).

22. Y. Li, B. Tan and Y. Wu, J. Am. Chem. Soc., 128, 14259 (2006).

23. C. Tang, Y. Bando, B. Liu, and D. Golberg, Adv. Mater, 17, 3005 (2005)

24. D. Zhang, H. Fu, L. Shi, J. Fang, and Q. Li, J. Solid State Chem., 180, 654 (2007).

25. X. Shi, S. Han, R. J. Sanedrin, C. Galvez, D. G. Ho, B. Hernandez, F. Zhou, and M. Selke, Nano Lett., 2, 289 (2002).

26. T. Li, S. Yang, L. Huang, and B. Gu, Nanotechnology, 15, 1479 (2004).

27. M. Nobial, O. Devos, O. R. Mattos, and B. Tribollet, J. Electroanal. Chem., 600, 87 (2007), and references therein.

28. G. H. A. Therese and P. V. Kamath, Chem. Mater, 12, 1195 (2000).

29. P. Bocchetta, M. Santamaria, and F. Di Quarto, Electrochem. Commun., 9, 683 (2007).

30. M. Lai, J. A. G. Martinez, M. Grätzel, and D. J. Riley, J. Mater. Chem., 16, 2843 (2006)

31. J. Oh, Y. Tak, and J. Lee, Electrochem. Solid-State Lett., 7, C2 (2004).

32. M. Santamaria, E. Adragna, and F. Di Quarto, Electrochem. Solid-State Lett., 8, B12 (2005).

33. M. Barsoum, Fundamentals of Ceramics, McGraw-Hill, New York (1997), p. 103.

34. A. J. Aldykiewicz, A. J. Davenport, and H. S. Issacs, J. Electrochem. Soc., 143 147 (1996).

35. F.-B. Li, R. C. Newman, and G. E. Thompson, Electrochim. Acta, 42, 2455 (1997).

36. T. Yoshino and H. Masuda, Solid State Ionics, 165, 123 (2003).

37. P. Bocchetta, C. Sunseri, G. Chiavarotti, and F. Di Quarto, Electrochim. Acta 48, 3175 (2003), and references therein

38. M. A. Centeno, C. Portales, I. Carrizosa, and J. A. Odriozola, Catal. Lett., 102, 289 (2005) 